This is an Accepted Manuscript of an article published by Edinburgh University Press in Journal of Qur'anic Studies, 22 (2). pp. 60-85 The Version of Record is available online at: https://www.euppublishing.com/doi/10.3366/jqs.2020.0425

Accepted version downloaded from SOAS Research Online: http://eprints.soas.ac.uk/32294

\title{
Sūrat Maryam (Q. 19): Comforting Muḥammad
}

\author{
M.A.S. Abdel Haleem \\ SOAS UNIVERSITY OF LONDON
}

\section{Introduction}

Mary is a very important figure in the Qur'an. Her name occurs 34 times, and most of these citations are connected to Jesus, who is normally referred to as is $\bar{a}$ bin Maryam ('Jesus, son of Mary'). This description points out immediately that Jesus had no father and indicates that, in the Qur'an, he is not 'son of God' but is son of Mary. In the light of this, the distinction given to Mary (the only woman to be mentioned by name in the Qur'an) of having a sura named after her is not surprising. When, in Q. 3:42, the angel speaks to her, saying 'Mary, God has chosen you and purified you. He has chosen you above all other women', three actions are mentioned: Mary is 'chosen', 'purified', and 'chosen above all women'. The first two are shared by others in the Qur'an, ${ }^{1}$ while the third is unique to Mary. We may understand this as heralding the unique status of her having conceived when no man has touched [her] (Q. 19:20), and of being the mother of Jesus.

Two important sections in the Qur'an are devoted to Mary: Q. 3:33-50 and Q. 19:1636. There are, in addition, more passing references, such as in Q. 23:50 and Q. 66:12. Over and above this, Sura 19 is named after Mary, even though she actually speaks only three sentences in it and most of the sura is about other people.

Because of the importance of Mary for Muslims and Christians, and for interfaith relations, much has been written about this sura. In recent times, attention has particularly been given to its structure. ${ }^{2}$ For example, in an article published in JQS in 2011, Shawkat Toorawa surveyed and tabulated three of these structural studies (by Bilal Gökkir, Angelika Neuwirth, and Neal Robinson), and is of the opinion that all three scholars are ultimately interested in proving that the sura exhibits structural coherence. He himself states his hope that: ${ }^{3}$

\footnotetext{
...that the foregoing has made clear, in order to better discern a sura's rhetorical structure one needs to know how all the words in that sura are deployed. Only with such a comprehensive lexicon are we in a position to see in detail and in relief how the entire sura operates lexically, acoustically and rhetorically.
}

Accordingly, he provides a list of all the words in Sürat Maryam, saying he hopes 
others will make 'maximal use' of it, and that 'analysis of word deployment in the sura will contribute to a better understanding of the sura's rhetorical structure'. ${ }^{4}$

In a more recent article, also published in JQS, Leyla Ozgur Alhassen provides a structural study of the first 58 verses of Sürat Maryam. ${ }^{5}$ She says in her introduction, 'The objective is ... to analyse the existence of, and the possible narrative reasons for, ambiguity within the text itself: what purpose does such vagueness fill? ${ }^{6}$ Her aim is to 'show how the structure of Q. 19:1-58 is developed through lexical echoes and repetition, and that the structure serves a narrative and thematic purpose'. ${ }^{7}$

Identifying the structure within the sura is of course important, especially in view of the way the material is presented in the Arabic Qur'an, which sets out the entire sura in continuous text, without any divisions or paragraphs, apart from the markers at the end of each verse. Structural analysis identifies the main subject topics, which is useful, but there is a danger that it can remain in the realm of form and dismember the material, overlooking the message and purpose that runs throughout each sura. Forms and literary analysis are important but only insofar as they indicate topics and meanings and show the purpose of the entire sura. In this article, I seek to undertake a structural analysis of Sürat Maryam which identifies a different structure from those outlined by previous scholars (see below, Table 1). However, before doing so, I will discuss the theme and purpose of this sura, which I maintain is to provide comfort and reassurance for the Prophet Muhammad, and how these have influenced my analysis of structure.

\section{Sūrat Maryam: Theme and Purpose}

Sūrat Maryam is characterised throughout by its juxtaposition of a series of accounts of earlier prophets and repeated mention of the stubborn disbelievers of Mecca, which can also be seen in many other places in the Qur'an. ${ }^{8}$ In Sūrat Șad (Q. 38), for instance, after mentioning the disbelievers' verbal attacks on the Prophet Muhammad and rejection of the message, from verses 1-16, the Qur'an addresses the Prophet, saying isbir 'alā mā yaqulūna wa'dhkur 'abdanā Dāwūd (Bear patiently with what they say and remember Our servant David). David here is given blessings by God, so it reminds the Prophet that God can and does give blessings to His messengers and can do the same for him. This combination of describing difficulties with the disbelievers and bringing in stories of earlier prophets is common in the Qur'an, in both long and short suras, and seems to occur mainly to comfort and encourage the Prophet and the believers and warn the disbelievers of the fate of others like them in the past (qablahum/min qablihim), an aspect which we shall see appearing in the last verse of Sürat Maryam.

The Qur'an states clearly the purpose behind its references to prophetic stories in Q. 11:120, So [Muhammad], We tell you the stories of the prophets to make your heart 
firm and in these accounts truth has come to you, as well as lessons and reminders for the believers. Stories of God's messengers play a part in many suras, but they fall within different contexts in different suras and are selected according to the requirements of these contexts. ${ }^{9}$ In line with the Qur'an's stated purpose of providing guidance for humankind (as laid out in Q. 3:3-4, Step by step, He has sent the Scripture down to you [Prophet] with the Truth, confirming what went before: He sent down the Torah and the Gospel earlier as a guide for people), it can be seen that the prophets of the past all preached the same message, the unity of God, His scriptures, and Judgement. The past disbelievers mentioned in these stories all raise the same objections as those who fail to believe in the message presented in the Qur'an, and in the end, God saves the believers and punishes the disbelievers.

Sūrat Maryam follows the general pattern of using stories of earlier prophets (and other figures) but is unique in all the Qur'an in two fundamental ways. First, the section outlining the trouble the disbelievers make and their fate is placed right at the end of the sura while stories recounting God's favour to the prophets occur at the beginning. Secondly, God's favour to these prophets is depicted as being very special, involving God showing His rahma ('mercy', 'grace') to them. In the prophetic section of this sura, nothing is found of the punishment mentioned in other suras. Moses, everywhere else in the Qur'an, is seen in relation to Pharaoh's oppressiveness and how Pharaoh was destroyed; in Sūrat Maryam only God's mercy to Moses is mentioned. Likewise, Abraham's story in Sürat Maryam has no mention of him destroying the idols or being thrown into a fire, as there is in some other suras. It is clear, therefore, that God's rahma to the prophets is the core theme and spirit of Sürat Maryam, which singles it out in the Qur'an, the question is 'Why?'

In my opinion, the answer is that this sura reflects the situation and the psychological need of Muhammad at the time of its revelation. Maryam is not an early Meccan sura but was revealed, according to Nöldeke, in the second period of the Meccan Qur'an, at a time when the Meccan disbelievers' contemptuous and oppressive treatment of the Muslims was growing, and the Prophet and his followers were faced by the threat of torture and death at their hands. Indeed, in the fifth year of Muhammad's thirteen years' preaching in Mecca, some of the believers had already been forced to emigrate to Abyssinia. However, there is nothing in the asbāb al-nuzūl ('causes of revelation') literature to specify which exact year the sura was revealed. ${ }^{10}$ My estimate is c. 618 , based on the dating, given by Nöldeke, ${ }^{11}$ that many suras were revealed in Mecca before and after Sūrat Maryam. If correct, this would bring it to about eight years after 610 , the start of the revelation, and around four years before the Prophet's migration to Medina. We have to derive the psychological state of the Prophet mainly from what is stated in the text. It is noticeable that the previous sura (Q. 18:6) asks Are you going to worry yourself to death because they do not believe? and the following one (Q. 20:2) We have not sent the Qur'an down to distress you. 
Sura 19 , therefore is part of a comforting series. This is clear from beginning to end as will be seen in the analaysis below.

After the isolated letters in verse 1, which alert the Prophet and his audience, indicating that what follows is scriptural revelation, in verse 2 we have dhikru rahmati rabbika 'abdahu Zakariyyā ([Muhammad, this is] an account of your Lord's grace (rahma) towards His servant, Zakariyyā. It should be noted that God is referred to as your Lord, so 'your' (second person singular) is specifically addressed to Muhammad. The Qur'an responds to situations and comments on them, and this statement suggests that the Prophet needed to be reminded of God's blessings to earlier prophets. The context must therefore be his being weighed down by his seeming lack of progress in convincing the disbelievers and the difficulty of his task. He was hoping to hear of some relief, hence rahmati rabbika 'abdahu (the grace of your Lord, to His servant), indicating that Muhammad's Lord could give grace to him as well. The use of the word rabbika here is significant. Rabbika means 'your cherishing Lord', which makes this address more personal than saying, for example, rahmati'llāhi 'abdahu. This provides an indication that the verse is a response to the Prophet's needs and hopes. In fact, God is referred to as rabb many times in this comforting sura and it is one of its recurring key words.

This is one example of an important feature of the Qur'an, which I have identified and termed radd (in the sense of 'response'). ${ }^{12}$ This occurs when the Qur'an responds to an unstated situation as we have here in Sürat Maryam. To give another example, in Sürat al-Duhāa, for instance, after the initial confirming oath, God says Your Lord has not forsaken you [Prophet], nor does He hate you (Q. 93:3). This verse was a response to the disbelievers' saying that Muhammad's God had forsaken him, following a gap between revelations. The Qur'an ignores what they say, without paying it any attention and goes straight into the radd. One aspect of the radd phenomenon is that the Qur'an concentrates on what matters, leaving unspoken the situation or event that prompted it. Learning to recognise the presence of radd in any particular situation is really important because, without it, there can be no awareness of the context, and readers might even wonder why certain things are mentioned at all.

To return to Sürat Maryam, the words dhikru rahmati rabbika 'abdahu ([This is\} an account of your Lord's grace towards His servant) that open the sura, and the stories that follow, give a strong indication of a situation that required radd. ${ }^{13}$ Other crucial instances of radd will be pointed out, as this analysis of Sürat Maryam continues, showing the importance of context in explaining why things are mentioned. The radd determines why certain figures are mentioned and how much and what exactly is said about them, as well as the focus of the stories referenced and told: examining the choice of such material confirms the existence of radd, as will be seen in the discussion taking place in this article. Viewing Sura 19 from the perspective of its 
purpose will show the inseparable connections between the two parts and will explain what is seen by some scholars as unexplained.

\section{Analysis of the Sura}

Qur'an 19, a Meccan sura, consists of 98 verses. In my opinion it can be divided structurally into 16 sections, numbered as follows:

\begin{tabular}{|c|c|c|c|}
\hline \multirow[t]{11}{*}{ Part 1} & 1 & $1-15$ & Zakariyyā \\
\hline & $1 b$ & $12-15$ & Subsection on John \\
\hline & 2 & $16-29$ & Mary \\
\hline & 3 & $30-36$ & Jesus \\
\hline & 4 & $37-40$ & Differences among following generations \\
\hline & 5 & $41-50$ & Abraham \\
\hline & 6 & $51-53$ & Moses \\
\hline & 7 & $54-55$ & Ishmael \\
\hline & 8 & $56-57$ & Idrīs \\
\hline & 9 & $58-63$ & $\begin{array}{l}\text { Summary of these prophets, followed by mention of } \\
\text { the subsequent generations' misbehaviour; rewards } \\
\text { for the good and recompense for the bad. }\end{array}$ \\
\hline & 10 & $64-65$ & Address by the angels to Muhammad \\
\hline \multirow[t]{6}{*}{ Part 2} & 11 & $66-72$ & Denial of the Resurrection \\
\hline & 12 & $73-76$ & Jeering at the believers \\
\hline & 13 & $77-80$ & Presumptuous disbelievers \\
\hline & 14 & $81-87$ & Idolatry \\
\hline & 15 & 89-96 & Countering the attribution of offspring to God \\
\hline & 16 & 97-98 & $\begin{array}{l}\text { Final address to the Prophet and mention of the } \\
\text { punishment of earlier generations }\end{array}$ \\
\hline
\end{tabular}

We will now deal with each of these sections in turn.

\section{Section 1: Zakariyyā and John (Q. 19:1-15)}

The first section starts with the isolated letters $k \bar{a} f-h a-y \bar{a}-$ 'ayn-șad, which form the first verse and are unusual both in their number and combination. I will not enter here into the traditional speculation about the meanings, other than stating that they alert the reader that what is coming is a divine scripture. The important thing is what they announce. 
It has been observed above that the context in which these verses were revealed was a situation where the Prophet needed reassurance. This required positioning the verses about prophets before those that address his troubles with the disbelievers of Mecca. This very same context and need required that Zakariyyā's story be placed at the beginning, as it is the most telling story in the situation, although chronologically he lived much later than the others mentioned.

The sura thus starts [This is] an account of your Lord's grace to His servant Zakariyyā. (Interestingly here, God puts this as an account (dhikr) whereas in the following stories he will say wa'dhkur ['remember'].) When Zakariyyā calls to his Lord nidā'an khafiyyā (with a secret call), it should be noted that this is not the whole story of Zakariyyā but an account of one particular moment idh nādā (when he called). The same connector idh followed by a past tense will be used again in this sura to introduce Mary and a number of prophets. With Moses, Ishmael, and Idrīs there is a description of each prophet (innahu kānā ['he was']) followed by a characterising adjective. What is given in this sura is not the full story of any one person but a concentration on one aspect of each story that serves the purpose of the sura.

In verse 4, Zakariyyā calls to his Lord secretly, saying, My Lord, my bones have become weak and my hair has turned ashen grey (rabbī innī wahana'l-'aẓmu minnī wa'shta 'ala'l-rā'su shayban), very soft expressive words in Arabic, with plenty of nasal consonants and vowels, showing him in earnest submission of prayer. More than anyone else in the sura, his weakness and submission reflect the state of the Prophet Muhammad at this time, so it is fitting that it should come first to reassure and comfort Muhammad. This is beautifully followed by the phrase, Never Lord, have I ever prayed to you in vain, an expression confirming his hope. He continues, in verse 5:

'I fear what my kinsmen will do when I am gone, for my wife is barren, so grant me from You, Lord, someone close who can be my heir, and an heir to the House of Jacob.'

Zakariyyā is not concerned about himself alone but also about the continuation of the line of prophethood from Jacob. 'Make him pleasing, my Lord' another touching request made in verse 6 , is left open to all-God, his parents, and everyone else. The repetition of 'my Lord' shows his most earnest devotion and desperate entreaty. Not surprisingly the answer comes instantly, in verse 7, announced by God Himself in the plural of majesty:

'Zakariyyā, We give you the good news of a son (innā nubashiruka bighulām), whose name will be Yahya (John), a name (samiyyan ${ }^{14}$ ) we have not given to anyone before'.

This instant answer to a request is more than can be found in any of the other stories 
in this sura and is meant to give comfort to Muhammad and the believers. The rhythm and rhyme of this prayer and answer are very expressive of this atmosphere of entreaty and divine granting. Apparently Zakariyyā wanted further confirmation, in his delight and amazement, saying, 'Lord, how can I have a son when I am so old?' The reply comes (in verse 9), Thus your Lord has said, 'It is easy for me: I created you before when you were nothing.' This shows the unquestionable power of God and the decision He has made. Zakariyyā further pleads, 'Lord, give me a sign', and is told, 'Your sign is that you will not speak to people for three days although there is nothing wrong with you.' So, he went out from the sanctuary to signal to the people to glorfiay God morning and evening .

Then, in verse 12, the Qur'an makes a time-leap to what is relevant to the context, omitting all the stages in between, and speaks to John, saying John, hold on to the Scripture firmly, a reminder of Zakariyyā's request for his son to carry on the heritage of the House of Jacob (i.e. the Scripture). The leap does not affect the reader's understanding of the story or what is particularly relevant in it. This is important because we will come across another leap in this sura. In answer to Zakariyyā's request to 'Make him pleasing, Lord', God says, in verses 12-13, While he was still a boy, We granted him wisdom, tenderness from Us, and purity. He was devout, kind to his parents, not domineering or rebellious. Peace on him the day he was born, on the day of his death, and on the Day he is raised to life again.

We should point out here that giving John wisdom as a boy contrasts with what is said about Joseph and Moses, who were given wisdom at a much later age. ${ }^{15}$ The words used to describe John in Arabic are all soft with nasal sounds, rhythm, and rhyme that enhance the lovely picture of the boy, ending with 'peace upon him' in his three main transition points of his life, birth, death, and resurrection, a fitting beginning for the purposes of this sura.

It is important at this point to compare the treatment of Zakariyyā and John in this sura with that in Sürat al-Anbiya ') (Q. 21). The treatment in Sura 19 is determined by the fact that it is a radd - a response to Muhammad's situation at the time. Zakariyyā is brought in, right at the beginning of the sura. In Q. 21:48-91 the Qur'an mentions sixteen prophets and then Mary. Zachariya comes as number fifteen in this list and the treatment is quite obviously different: Remember Zakariyyā, when he cried to his Lord, 'My Lord, do not leave me childless, though You are the best of heirs (Q. 21:88). The treatment here is short, matter-of-fact, and God reports, We responded to him and granted him John. This contrasts with the desperate yearning and weakness that is made clear in Q. 19. The report, We responded to him contrasts with God addressing Zakariyyā personally in Q. 19:7, We give you the good news of a son, whose name will be John, a name we have not given to anyone before. This shows that the Qur'an does not merely repeat prophetic stories but selects, expands, and gives different angles on them depending on the context. 
Section 2: Mary (Q. 19:16-29)

After Zakariyyā and John, starting at verse 16, comes the section on Mary. Like all the following stories, it is introduced by singular imperative, addressed to Muhammad: wa'dhkur fi'l-kitāb ('Prophet,] remember, ${ }^{16}$ in the Scripture'). It is significant that, in this sura alone, ${ }^{17}$ we have fi'l-kitāb (in the Scripture) after wa'dhkur, with Mary and all the following stories, to emphasise that this information is part of the Scripture. It is interesting too that John is told khudh al-kitāb (take the Scripture) but Jesus says, $\bar{a}$ tāni'l-kitāb (He gave me the Scripture). Both these references to the Scripture show how important it is. This order of material here is logical since God put Mary in Zakariyyā's charge (kaffalahā, Q. 3:37). These stories are put together in the same order in Suras 3, 19, and 21. The narration starts in Sura 19 from the point where Mary isolates herself from her people, introduced by idh. Nothing of the story of Mary is mentioned before that point. It is useful here to refer to the story of Mary as related in Q. 3:35-47 to get earlier information as it has a bearing on the way she behaves in Sūrat Maryam:

Imran's wife said, 'Lord, I have dedicated what is growing in my womb entirely to You; so accept this from me. You are the One who hears and knows all,' but when she gave birth, she said, 'My Lord! I have given birth to a female!'-God knew best what she had given birth to: the male is not like the female-'I name her Mary and I commend her and her offspring to Your protection from the rejected Satan.' Her Lord graciously accepted her and made her grow in goodness, and entrusted her to the charge of Zakariyyā. Whenever Zakariyyā went in to see her in her sanctuary, he found her supplied with provisions. He said, 'Mary, how is it you have these provisions?' and she said, 'They are from God: God provides limitlessly for whoever He will.' There and then Zakariyyā prayed to his Lord, saying, 'Lord, from Your grace grant me virtuous offspring: You hear every prayer.'

Mary's mother is depicted here as a very pious woman, dedicating her unborn child to serve God in the sanctuary. She was expecting a boy, so she said, apparently in an apologetic tone, 'I have given birth to a female'. Before she continues, God interrupts to say He knows better than she does, which suggests that her female child is better than the son she had expected. God continues, the male is not like the female. (The definite article al- here is not generic but ahdiyya, meaning that the male she had expected is less than the female she has given birth to.) She continues, 'I name her Mary and I commend her and her offspring to Your protection from the rejected Satan.' A mother seeking to protect her newborn baby from Satan is expected but what is remarkable here is that she extends this prayer to protect the baby's offspring. Little did she know that she was praying for Jesus Christ to be protected! 
When, later, Zakariyyā asks Mary about the food that appears mysteriously, she explains that all that comes to her is from God, who provides without measure. Zakariyyā is seen to have learned something from this and begins to ask God to give him a son. After Zakariyyā's prayer we are told, in Q. 3:42-43:

The angel said to Mary: 'Mary, God has chosen you and made you pure: He has truly chosen you above all women. Mary, be devout to your Lord, prostrate yourself in worship, bow down with those who pray.'

Having drawn this picture from Sura 3, we can now return to Sura 19, which begins its Mary account after she has withdrawn from her people and screened herself from them, which seems to be part of what God ordered her to do, ${ }^{18}$ at a point when an angel appears to her in the form of a perfect man. Her reaction is to be expectedshe is worried about her chastity (see also Q. 66:12). Immediately, after seeing the angel/perfect man suddenly appear to her in her isolation she says, 'I seek protection with the Lord of Mercy (al-rahmān) from you' (Q. 19:18). ${ }^{19}$ Thus, Mary's immediate reaction to this perceived threat is to resort to God for protection. The angel explains that, rather than being a source of danger she should fear, he is a messenger from God, come to announce to her the gift of a pure son (Q. 19:19). Like Zakariyyā she cannot understand how this can happen, responding 'How can I have a son when no man has touched me? I have not been unchaste.' She does not react with anger but with shock and asks for an explanation. The answer he gives her is the same as the one given to Zakariyyā, but with added reassurance: 'This is what your Lord said: "It is easy for $\mathrm{Me}^{20}$-We shall make him a sign to all people, a blessing from Us (rahmatan minnā)"'.' The word rahma recurs many times in this sura, which suits the purpose of the sura. The answer concludes with, And so it was ordained: she conceived him.

Here we find reassurance, combined with the Divine decree which cannot be altered. We shall return to this point later in the discussion. The narration now leaps again from conception to the point of giving birth, when Mary is forced to find support from a palm tree in a distant place in Q. 19:22-26:

She withdrew to a distant place and, when the pains of childbirth drove her to [cling to] the trunk of a palm tree, she exclaimed, "I wish I had been dead and forgotten long before all this!'but a voice cried to her from below, 'Do not worry: your Lord has provided a stream at your feet and, if you shake the trunk of the palm tree towards you, it will deliver fresh ripe dates for you, so eat, drink, be glad, and say to anyone you may see: "I have vowed to the Lord of Mercy to abstain from conversation, and I will not talk to anyone today."'

Mary's reaction in verse 23 is natural for a young woman giving birth for the first 
time, alone and unsupported, but then a voice calls out to her to reassure her 'from below' and point out that she has dates and water to sustain her and tell her to shake the palm tree [gently] towards her, and it will drop down (tusāqiț-a continuing process) fresh dates. This is for further reassurance (so eat, drink and be glad). This recalls the provisions sent to Mary by God while she was in seclusion in the Temple (fi'l-mihrāb). The identity of the owner of the 'voice' in this passage is unspecified, and this has given rise to much discussion. Some have said it was the baby Jesus speaking, and that this is another of his miracles. Others have objected that this interpretation is not suitable because there would be blood underneath her. ${ }^{21}$ More recently, Leyla Ozgur Alhassen sees this gap in information as one of a number of 'secrets' kept in this sura. ${ }^{22}$ In my opinion, by looking at other parts of the Qur'an, an explanation can be found. In Q. 23:50, we are told: We made the son of Mary and his mother a sign: We sheltered them on a hillside above a low land (qarrār) with a flowing spring. This suggests to me that min tahtiha means 'further down the hill'. My opinion is that the angel who appeared first to reassure her is now coming back to reassure her once again at the time of giving birth.

Going back to Sura 19, the text now continues (verses 26-29): When you see any human, say: "I have vowed to the Lord of Mercy to abstain from conversation, and I will not talk to anyone today.' 'Say', here, has been understood by translators to mean 'say to any human', which results in seeing a contradiction: how can she say anything to anyone when she is abstaining from conversation? 'Say', in Arabic, can also mean 'say to yourself ...'. This reading of the text is supported by the fact that Mary is supposed to say it, not when someone speaks to her but when she sees someone-this can mean 'even at a distance' - and 'remind yourself that you are not going to speak to them', so there is no contradiction in this statement. This section concludes with an account of her return to her people:

She went back to her people carrying the child, and they said, 'Mary! You have done something terrible! Sister of Aaron! Your father was not a bad man; your mother was not unchaste!' She pointed at him. They said, 'How can we converse with an infant (man kāna fi'l-mahdi șabiyyan)?' 23

When she goes back to her people, carrying him, and they assume she has done something terrible, Mary merely points to her son, because she has vowed not to speak. They address her as sister of Aaron and say that her father was a good man and her mother was not unchaste. ${ }^{24}$

Section 3: Jesus (Q. 19:30-36)

The Qur'an moves straight on, in Q. 19:30-33, to recount a speech made by Jesus:

He said: 'I am a servant of God. He has granted me the Scripture; made 
me a prophet; made me blessed wherever I may be. He commanded me to pray, to give alms as long as I live, to cherish my mother. He did not make me domineering or graceless. Peace was on me the day I was born, and will be on me the day I die and the day I am raised to life again.'

The placing of this verse in the sura, coming straight after the people's questioning of Mary makes many exegetes and commentators, past and present (with, to my knowledge, one exception ${ }^{25}$ ), believe that Jesus spoke instantly at that time. Thus, for example, Leyla Ozgur Alhassen says that he, 'defends his mother from people's accusations' ${ }^{26}$

The statement she pointed at him followed, almost immediately, by the verb qãla ('he said') also strengthens this impression. There are many Qur'an reciters who select this story, of the Annunciation and Jesus speaking, particularly to show off their excellent performance. The public become greatly excited and glorify God for this miracle, especially as some join the two verses in one breath, intensifying the feeling that Jesus spoke at that time. However, I have come to hold the view that Jesus did not speak at that moment and that what is said here came much later in his life. As mentioned above, there is another example in this sura, in verse 64 , of a similar Qur'anic time-leap in the story of John. In addition, in Q. 20:40 God reminds Moses of a list of His blessings on him, jumping from how He saved him and returned him to his mother, to the moment that Moses killed a person and We saved you from distress, which came much later in his life. In the Qur'an, the textual adjacency of events does not necessarily mean that they occurred at the same time. Moreover, the statement given by Jesus does not, as one might expect in these specific circumstances, defend the innocence of his mother, otherwise he would have said, 'My mother is innocent and God created me without a father,' as in Q. 3:59-60: In God's eyes Jesus is just like Adam: He created him from dust, said to him, 'Be', and he was. This is the truth from your Lord, so do not be one of those who doubt.

This section serves two purposes, starting from verses 32-33. First, declaring the oneness of God, and then declaring the blessings of God on Jesus. It is easy to imagine that the Prophet Muhammad would have been very pleased to recite Jesus' statement as it responds to his desire to hear about God's mercy, in the psychological state he was in, that gave rise to this sura. In addition to the sense, the rhythm and sound quality of the words themselves are moving.

As regards the first purpose, Jesus' statement in Sura 19 works to counter the idea that Jesus was the son of God. The text itself gives two proofs of this.

1) The first thing he says is 'I am a servant ('abd) of God.' This is followed by a list of six things which Jesus deliberately attributes to God, all of which confirm that he is a servant of God. 
[Jesus] said: 'I am a servant of God. He has granted me the Scripture; He made me a prophet; He made me blessed (ja 'alani) wherever I may be. He commanded me to pray, to give alms as long as I live, to cherish my mother. He did not make me domineering or graceless.

All these verbs are given in the past tense in Arabic which means that the statement comes after all these have happened, and they certainly did not happen immediately after his birth. He concludes that God has granted peace to him: 'Peace was on me the day I was born and will be on me the day I die and the day I am raised to life again.' It could be argued that ja 'alani in this passage means He ordained that I would be [in the future] .... ${ }^{27}$ This is doubtful because when the verb ja' ala is intended for the future it comes in the form of an active participle. For example, when Moses' mother is about to throw him into the river (Q. 28:7), God says, 'Don't be afraid or sad, (innā rāddūhu ilayki wa-jāi ilūhu min al-mursalīn), We are going to return him to you and make him a messenger. Similarly, God said to Abraham (Q. 2:124) inni jāiiluka li'l-nāsi imāmān (I am going to make you a leader of people). So, the past tense verbs in the statement by Jesus must be taken at face value.

2) The second proof is that at the end of this statement God says (Q. 19:34-36):

Such was Jesus, son of Mary. [This is] a statement of the Truth about which they are in doubt: it would not befit God to have a child. He is far above that: when He decrees something, He says only, 'Be,' and it is. God is my Lord and your Lord, so serve Him: that is a straight path.

This is clearly an answer to people who said later about Jesus that he was the son of God. Mary's people could not in any way have thought that he was the son of God, quite the reverse, after saying, 'You have done something terrible ...'

At the end of this statement, God is my Lord and your Lord, so serve Him. Some scholars $^{28}$ thought that this could have been said either by Jesus or Muhammad, seeing it as ambiguous. In fact, it could not be said by Muhammad, there is no place for him here, and it is clear from Q. 3:51 that Jesus said it.

We are now left with the difficulty of the question, 'How can we converse with a baby in the cradle?' To answer this, we need to look at the use of specific wording in other places in the Qur'an, taking first the phrase fi'l-mahd, which is often read as 'in the cradle'. The phrase fi'l-mahd is also found in the Qur'anic statement about Jesus speaking in Q. 3:46, He will speak to people in his infancy and in his adulthood (yukallimu'l-nāsa fïl-mahdi wa-kahlan), and in Q. 5:110, you [Jesus] spoke to people in infancy and as a grown man (tukallimu'l-nāsa fi'l-mahdi wa-kahlan). In addition, in Q. 19:29 Jesus is described as fi'l-mahdi șabiyyan. ${ }^{29}$ The word mahd means 'a place smoothed out for a small child to sleep in'. Although often translated as 'cradle', it is not a piece of furniture like a cradle. It does not confine the age of the child to the 
same extent as a cradle. ${ }^{30}$ Rather than meaninig physically 'in the cradle' fíl-mahd can often mean 'in a particular phase of life', just like fi'l-shabāb ('in youth') or fílkuhūla ('in middle age') or fïl-shaykhūkha ('in old age').

We now turn to the phrase yukallimu'l-nās. This does not seem to mean simply 'speak to people', but 'speak sensibly to people'. There is no sense in saying that he spoke to people when older, there is nothing unusual about this. It means to speak with sound judgement, as God says about John, and We gave him sound judgement as a boy (șabiyyan). ${ }^{31}$ When Mary is told in Q. 19:19 by the angel that she would have a ghulāman zakiyyan, zakiyy can mean 'pure' but also 'spiritually and intellectually growing', hence this phrase can be read as saying that Jesus is more spiritually and intellectually developed than other children of his age. This is not to deny that God has the ability to make an infant speak-the creation of the baby itself is more miraculous than that-but simply, that contextual and linguistic analysis and intratexual references support the argument outlined in this study.

When I mentioned my reading of this passage to a number of Muslim scholars their automatic response was to ask, 'But what about the hadith?' So, at the risk of digressing, we must now address a hadīth ahad that is found in al-Bukharī's (and Muslim's) Sahīh, where it is reported as being narrated by Abū Hurayra. The hadīth itself is as follows: 'The Prophet said, "None spoke in the cradle but three ...", and goes on to mention Jesus and recount two anecdotes about other figures. ${ }^{32}$ The hadith mentions Jesus only by name without giving any further context, however the other two are elaborated. The second figure to be mentioned is a pious man from the Banū Isrā'ill, named Jurayj, who refused the temptations of a whore. The woman then approached a shepherd, became pregnant, and accused Jurayj of being the father. The baby was asked who its father was and replied, 'The shepherd'. In the third instance a woman from the Banū Isrā'îl who was suckling a baby saw a handsome rider and prayed for her baby to become like him, to which the baby retorted, 'Don't let me be like him.' Both narrations are about Banū Isrā'îl and in both the children reply with one or a few words. All the replies are relevant to the situation and the intention of the stories is the moral given, which is acceptable in Islam.

In Sürat Maryam, Jesus gives a long speech following the passage in which Mary points at him and, as we have seen, it has no relevance to the accusations against Mary. Since the hadith mentions only that Jesus was one of these three who had spoken 'in the cradle' it cannot be taken for granted that it refers unambiguously to his long statement in Sürat Maryam. It is possible, given the other stories in the hadith quoted, that if he had uttered anything it would have been to exonerate his mother. This hadīth, narrated by Abū Hurayra is a hadīth ahad, suitable for moral guidance but which cannot be relied upon in a matter of faith, against all the linguistic and contextual evidence above, to assert that Jesus' long statement was uttered when he was a baby. Matters of faith can only be established by what is qat $\bar{T}$ al- 
thubūt (categorically established by indisputable evidence from the Qur'an or hadith mutawātir) and qat'i al-dalāla (categorically and unambiguously meaning what it is claimed to mean). ${ }^{33}$ The hadith in question here is neither categorically established nor can it be established that it was referring to the story in Sürat Maryam.

If, as we have argued, Jesus' statement was not uttered in infancy, we still need to explain what happened after Mary pointed to him and her people said, 'How can we speak to an infant (man fi'l-mahdi șabiyyan)?' Perhaps this was a rhetorical question to which they did not expect an answer. The Qur'an keeps silent at this point, just as it keeps silent after Zakariyyā signals to his people to glorify God. As explained above, there is a leap forward to speak to John, telling him to take to the scripture strongly. We have pointed out that such time-leaps are normal in the style of the Qur'an as it goes on to what is relevant to the message of the sura. The leap here is to make Jesus speak of what is most fundamental in his life and message, 'I am a servant of God, He gave me the scripture ... God is my Lord and your Lord, so worship Him. This is the straight path.' If Jesus had indeed spoken from the cradle, surely Mary's people would have glorified God and spread the news to everybody to declare her innocence in the strongest way? There is no record of them doing this and it is clear from the Qur'an (Q. 4:156) that their accusations persisted.

\section{Section 4: Differences among Following Generations (Q. 19: 37-40)}

This section, which addresses how factions have differed among themselves, and foretells what suffering will come to those who obscure the truth when a dreadful Day arrives, appears to continue to refer to followers of Jesus who have come after he has decisively rejected any claim to be the son of God. The Qur'an warns such people about what they will face on the Day of Judgement. concluding with the affirmation that all will be returned to God for justice.

\section{Section 5: Abraham (Q. 19:41-50)}

After departing from chronology and placing Zakariyyā, Mary, and Jesus first, to suit the context of the story, in Q. 19:41-50 the Qur'an makes another time-leap backwards in history from Jesus to Abraham. In my opinion, the placement of this story about Abraham here serves to emphasise the Qur'an's affirmation of tawhid (monotheism) and denial of any shirk (polytheism), both in the case of Jesus and then Abraham. The story begins with wa'dhkur fi'l-kitab (Remember, too, in the Scripture), which is repeated here to for emphasis and to impress the message (or reminder) on the mind of Muhammad. This story of Abraham is the first of several, which are given in the next few sections. In these, the Qur'an describes Abraham (Q. 19:41) and Idris (Q. 19:56) as siddīqan nabiyan (a true prophet ${ }^{34}$ ), and Ishmael is described (Q. 19:54) as sādiq al-wa'd (true to his promise). This recalls the compact God has made with prophets and the fact that he will question the șädiqin 'an șidqihim (the truthful 
about their truth, Q. 33:8). Each of the prophets mentioned in this sura has shown unwavering steadfastness in keeping their promises to God. In the case of Abraham, he keeps his promise to his father that he will ask God to forgive him, but God reprimands him for doing so (Q. 9:114). Abraham stays true to his vision, that God gave him, of sacrificing his only son (Q. 37:105). These references to being steadfast and true to God are given to Muhammad as reminders of good examples. The sura gives reassurance and teaching to him.

Abraham is concerned about his father but is very gentle with him, producing good persuasive arguments, asking:

'Father, why do you worship something that can neither hear nor see, nor benefit you in any way? Father, knowledge that has not reached you has come to me, so follow me: I will guide you to an even path. Father, do not worship Satan-Satan has rebelled against the Lord of Mercy. Father, I fear that a punishment from the Lord of Mercy may afflict you and that you may become Satan's companion [in Hell].'

However, his father's response is sharp: 'I will stone you if you do not stop this. Keep away from me for a long time!' Abraham answers with a greeting of peace and his promise to ask God for forgiveness. ${ }^{35}$ As noted above, Abraham's gentle and patient side is particularly emphasised in this sura. The passage concludes by mentioning God's blessing upon Abraham, to whom He grants (wahhabnā lahu) two offspring, Isaac and Jacob: We granted Our grace to all of them and gave them a noble reputation. This is another example in this sura of God extending his mercy and blessing (rahma) at times of difficulty, which is all reassuring to Muhammad, in keeping with the purpose of the sura.

Section 6: Moses (Q. 19:51-53)

In these two verses, (Remember too, in the Scripture, the story of Moses. He was specially chosen, a messenger and a prophet: We called to him from the right-hand side of the mountain and brought him close to Us in secret communion; out of Our grace (min rahmatinā) We granted him his brother Aaron as a prophet), Moses is described as mukhlasan ('chosen'), as well as a messenger and a prophet. God speaks in the plural of majesty to honour Moses, using again the key words, wahabna min rahmatinā (out of Our grace We granted him).

\section{Section 7: Ishmael (Q. 19:54-55)}

In chronological terms, these two verses urging believers to Remember, too, in the Scripture, the story of Ishmael. He was true to his promise, a messenger and a prophet. He commanded his household to pray and give alms, and his Lord was well pleased with him, should have come directly after those relating to Abraham, his 
father, but he and Idrīs are mentioned at the end of the sequence and with neither of them is the keyword wahhabna used. Ishmael is described as sādiq al-wa'd (true to his promise), ${ }^{36}$ and we are told that as a result of his pious behaviour he was blessed by God's pleasure with him (his Lord was well pleased with him).

\section{Section 8: Idrīs (Q. 19:56-57)}

This very concise reference to the stoyr of Idris (Remember, too, in the Scripture, the story of Idris. He was a man of truth, a prophet. We raised him to a high position), again, places the emphasis on the prophet mentioned being șiddī , and God blessing him by raising him to a high position.

This ends the narratives on e specially-selected prophets, with specially-selected qualities, to suit the purpose of the sura, as mentioned earlier, and nothing is included that is alien to this purpose.

\section{Section 9: Summary of these Prophets and the Subsequent Generations'}

Misbehaviour; Rewards for the Good and Recompense for the Bad (Q. 19:58-63)

All these prophets and their offspring are described in this section as being blessed by God (an 'ama a'llāhu 'alayhim), among those who were guided and chosen: When the revelations of the Lord of Mercy were recited to them, they fell to their knees and wept. They are put forward as examples for Muhammad and his community. After a warning about those generations who neglected prayer and were driven by their own desires, who come face to face with their evil, there follows a description of the joy that waits in Paradise for those who repent and do good deeds: There they will hear only peaceful talk, nothing bad; there they will be given provision morning and evening. We shall see how the disbelievers behave only in the final part of the sura.

\section{Section 10: Address by the Angels to Muhammad (Q. 19: 64-65)}

This section has been seen as enigmatic and disconnected ${ }^{37}$ but it is well connected to the previous material. These two verses, We only descend [with revelation] at your Lord's command - everything before us, everything behind us, everything in between, all belongs to Him-your Lord is never forgetful. He is Lord of the heavens and earth and everything in between, so worship Him: be steadfast in worshipping Him. Do you know of anyone equal to Him?' should be read as another example of a leap, this time of perspective. They are also an example of radd ('response'). Lexically it is clear that the first phrase ('We only descend [with revelation] at your Lord's command) must be spoken by angels. Then we have qasr ('restriction') in the sentence using negation and exception, $m \bar{a}$ and illa, which answers someone thinking or expecting otherwise, in this case the Prophet expecting the angels to come to earth, which suggests that Muhammad, having heard of the good blessings that came to earlier 
prophets must have wished for an angel to bring him similar blessings. The angels tell him that they only come down with the permission of God, who controls them all, and reassure him that his Lord is not forgetful, (he has not forgotten you). The key word in this verse is rabbika (your Lord) which is used at the beginning of the sura (the blessings of your Lord to His servant Zakariyyā) and is echoed here to connect both verses to the main theme of the sura. Without seeing this intentional repetition this connection can be missed. Muhammad is told, He is the Lord of the heavens and the earth and what is between them, so worship Him and be steadfast (wa'ștabir) in your worship. He is reassured but told to continue with his worship of God. This is categorical, just as is the case with Mary, when she is told This is a matter that is finally decided (amran maqdiya). Mercy is shown to her but there is no escape from what is decided: she must submit to God's decision, and so must Muhammad. He should persist in his worship in the face of what the disbelievers will say and do, in the final part of this sura, which has been delayed, contrary to the ordinary pattern, as mentioned earlier.

\section{Part 2}

This second part of the sura begins with wa-, a cohesive device that connects the two parts. Part 1 ends with the punishment in Hell of the disbelievers and the rewards for the good, with instructions to the Prophet to persevere in his worship, and Part 2 begins with discussion of the fate awaiting those who deny the Resurrection.

Section 11: Denial of the Resurrection (Q. 19:66-72)

The section opens with the verse, Man says (yaqūl al-insān), 'What? Once I am dead, will I be brought back to life?' The use of the word al-insān here clearly applies only to those who deny the Resurrection. ${ }^{38}$ It clearly does not include every human being, as prophets and other good believers are not included. We know from the Qur'an itself that such expressions of disbelief and doubt saddened the Prophet (Q. 6:33, Q. 20:130, Q. 36:75, and Q. 73:10) to the extent that he is asked, Are you going to worry yourself to death over them if they do not believe? (Q. 18:6 and Q. 26:3). He is told to be patient with what they say (fa'așbir 'ala mā yaqulūn). ${ }^{39}$

In Part 2 of the sura there are four instances of such troubling sayings and one action, in verse 81 , where the disbelievers deny the oneness of God (tawhīd) by taking other gods besides Him to support them and attributing offspring to Him. We note that the Qur'an in this section states their claim and then answers it, so, after the disbelievers question the Resurrection in verse 67, the Qur'an retorts with another question, Does man not remember that We created him when he was nothing before? ${ }^{40}$ After this counter-question, the Qur'an emphasises to the Prophet that the disbelievers will be brought back to God. God threatens the disbelievers, swearing by Himself, again calling Himself 'your Lord' (fa-wa-rabbika, a key phrase that has been used 
before, in verses 2 and 64 to strengthen Muhammad), By your Lord, [Prophet,] We shall gather them and the devils together and set them on their knees around Hell. This strong language comes in answer to stubborn disbelievers. It also contrasts sharply with the statements of belief in the Resurrection stated about John and by Jesus.

Section 12: Jeering at the Believers (Q. 19:73-76)

This section gives a second example of misbehaviour on the part of disbelievers, here talking about human ambition and greed (When Our revelations are recited to them in all their clarity, [all that] the disbelievers say to the believers [is], 'Which side is better situated? Which side has the better following?'). The misbehaviour of the disbelievers contrasts sharply with the actions of those who fall on their knees, weeping, when the revelations of God are recited to them earlier, in Q. 19:58. The arrogance of people like Abū Jahl was to keep saying, 'We have more wealth and children,' seeing that those who accept the revelation were only the weakest and lowest in society. This recurring argument is repeated in Q. 18:34, Q. 34:35, Q. 72:24, and Q. 74:13, among others. The Qur'an reports that the people of Noah said to him, 'We see that only the lowest among us follow you' (Q. 11:27).

This arrogance is countered in this section with the response, in verse 75: Say [Prophet], 'May the Lord of Mercy extend [more leeway] to the misguided, until, when they are confronted with what they have been warned about-either the punishment [in this life] or the Hour [of Judgement]-they realize who is worse situated and who has the weakest forces.' In the following verse, God counterbalances this with mention of His guidance for believers (But God gives more guidance to those who take guidance, and good deeds of lasting merit are best and most rewarding in your Lord's sight.)

\section{Section 13: Presumptuous Disbelievers (Q. 19:77-80)}

Have you seen the man who rejects Our revelation, who says, 'I will certainly be given wealth and children'? Has he penetrated the unknown or received a pledge to that effect from the Lord of Mercy? No! We shall certainly record what he says and prolong his punishment: We shall inherit from him all that he speaks of and he will come to Us all alone.

This short section, comprising three verses, provides a further example of arrogance and presumption by another disbeliever, who does not yet have any wealth or children, and the threat of the fate that awaits him. The speech of the man mentioned here, who says, 'I will certainly be given wealth and children', contrasts sharply with Zakariyyā's earnest prayer to God to grant him a son earlier in the sura. 
God rejects this man's presumption with a rhetorical question, Has he penetrated the unknown or received a pledge to that effect from the Lord of Mercy? and answers, God will inherit all his hoped-for wealth and children and he will return to God alone (fardā), a word which, as we will see later, recurs near the end of the sura, in Q. 19:95. ${ }^{41}$

\section{Section 14: Idolatry (Q. 19:81-87)}

This section begins by outlining the sin that accompanies all the spoken arguments above: They have taken other gods beside God to give them strength, but these gods will reject their worship and will even turn against them, following which God addresses the Prophet personally in verse 83 to ask Do you [Prophet] not see how We set evil ones on the disbelievers to incite them? Therefore he has no need to ask for their punishment to be hastened for them (fa-lā ta'ajal 'alayhim). This recalls the earlier order, given in verse 65, to be steadfast in your worship of Him (wa'ștabir li'ibādatihi). Then, in verses $84-87$, the fate of the disbelievers is described:

There is no need for you to be impatient concerning them: We are counting down their [allotted] time. On the Day We gather the righteous as an honoured company before the Lord of Mercy and drive the sinful like a thirsty herd into Hell, no one will have power to intercede except for those who have permission from the Lord of Mercy.

This power of intercession was assumed by the idolaters to be given to the daughters of God (i.e. the angels).

\section{Section 15: Attributing Offspring to God (Q. 19:88-96)}

Verse 88 states: The disbelievers say, 'The Lord of Mercy has offspring.' Claiming that God has offspring is shown here as the most terrible of their sins. It contrasts sharply with verse 35, It would not befit God to have a child. He is far above that. In a number of verses, the Qur'an makes it clear that it is God who creates and sustains the earth, the sky, and everything in between and beyond. ${ }^{42}$ It is all the more terrible, therefore, to attribute offspring to Him, as is described in Q. 19:89-95:

How terrible is this thing you assert! It almost causes the heavens to be torn apart, the earth to split asunder, the mountains to crumble to pieces, that they attribute offspring to the Lord of Mercy. It does not befit the Lord of Mercy [to have offspring]: ${ }^{43}$ there is no one in the heavens or earth who will not come to the Lord of Mercy as a servantHe has counted them all: He has numbered them exactly-and they will each return to Him on the Day of Resurrection all alone (fardā). 
God has numbered everyone in the heavens and the earth exactly and they are all, without exception, servants ( $a b d$ ) of God, the first description Jesus makes of himself in verse 30 above. Having finished with these disbelievers God promises a contrasting fate for the believers in Q. 19:96:

But to those who believe and do righteous deeds the Lord of Mercy will give love (sa-yaj 'alu lahumu'l-raḥmānu wudda).

Wudda ('love') is a word mentioned only once, here, in the Qur'an. It is related to alwadūd, one of God's beautiful names. It is fitting here, where it crowns the underlying theme of rahma in the first part of the sura, adding another dimension to it. This is a very special privilege compared with the treatment of people in the previous verse. It is paralleled in verse 63 , which also ends a section: that is the Garden We shall give as their own to those of Our servants who were devout.

\section{Section 16: Final Address to the Prophet (Q. 19:97-98)}

The sura ends with two verses devoted to instructing Muhammad in his prophetic duty- his sole task-to give good news and warning, not to convert people. They provide a reminder of the punishment of earlier generations:

We have made it easy, in your own language [Prophet], so that you may bring glad news to the righteous and warnings to a stubborn people. How many generations We have destroyed before them! Do you perceive a single one of them now, or hear so much as a whisper?

The good news comes first, to suit the first part of the sura, while warning comes second, just as the disbelievers come last. ${ }^{44}$ Having listed all the disbelievers' misdeeds, the sura concludes with another address to Muhammad, which comes as a response to what is unstated here: his worried state of mind. It starts with two particles, fa tafsiriyya (explanatory $f a$ ) and innamā (a particle of restriction), explaining and restricting his task to giving good news and warning. To supply the unstated state of mind, this means, 'So, you need not worry yourself about their persistence or attribute it to a failure in performing your task' ${ }^{45}$

The sura ends with further encouragement to the Prophet, in the form of a reminder of the fate of previous generations of disbelievers: How many generations We have destroyed before them! Do you perceive a single one of them now, or hear so much as a whisper? This final rhetorical question further engages Muhammad personally and reassures him that God will silence the present generation's objections too. Thus, as we can see, both parts of the sura gives him encouragement. At the sura level, it is worth remarking that the first word of the sura (after the isolated letters) is dhikr ('an account') and the final word is rikz ('a whisper') both of the same pattern fil. These words share two consonants ( $k \bar{a} f$ and $r \bar{a}$ ', with a minor difference in 
pronunciation between $d h \bar{a} l$ and zayn), so the letter sounds are almost in reverse order, contrasting speaking with silence, like the difference between mercy and destruction, rahmat rabbika (v. 2) and ahlaknā (v. 98). Thus, the assumption that the two parts of the sura are not connected, or that the first part can be dealt with separately are demonstrably incorrect. The contrast and connection between the parts of the sura is made obvious in the juxtaposition of dhikr, the everlasting 'account' mentioned in the Scripture, and the total annihilation of the earlier disbelievers, so that not even a whisper is heard from them.

\section{Conclusion}

The foregoing analysis highlights the way that both parts of the sura give encouragement to Muhammad and this purpose governs the structure. In fact, a prominent feature of this sura is that it is addressed to the Prophet from beginning to end, using second person pronouns, second person verbs, and direct imperatives. For example, phrases such as rahmati rabbika, wa'dhkur (several times), bi-amri rabbika, fa'sbir, fa-wa-rabbika, qul, fa-lā ta'jal, yasarnāhu bi-lisānika (We made it easy in your own language), hal tuhissu minhum min ahadin aw tasma 'u lahum rikza. The entire sura is a khitāb ('address') to the Prophet. Although the same is true of some shorter suras, such as Q. 93, Q. 94, Q. 108, and Q. 110, it is unusual to find it so clearly in one as long as Sūrat Maryam.

All this is further evidence to confirm that this sura is a response (radd) to the situation and the psychological state of a prophet who was in need of reminders of God's grace and encouragement, such as were given to all previous prophets, and who hoped for similar favour for himself. In Part 1, this comfort was provided through examples of God's grace to earlier prophets, and in Part 2 by countering what the disbelievers were saying and clearing him of any responsibility for their guidance, reminding him that many generations before them were destroyed and he cannot even hear a whisper from them. In between the two parts, in verse 64 , he is reminded that angels come down not at his request but only by God's permission. The fact that this verse ends with the phrase your Lord is never forgetful gives him hope that God has not forgotten him and that he will indeed be given the type of blessings that were given to earlier prophets. The function of this sura is completely fulfilled.

Of the six main figures in this sura, three pray for something: Zakariyyā, Abraham, and Moses. The verses about their prayers include the phrases hab lī ('grant me') or wahabnā ('We granted'). No prayers are mentioned either by Ishmael or Idrīs. Mary did not ask; it was ordained that she would be granted (ahaba laki) a good son (ghulāman zakiya). Out of all these figures, she is really the one who is depicted as going through personal suffering as a result of what she is given. But of course, God says, We will make him a sign for people and a grace from us (Q. 19:21). God also says, We made the son of Mary and his mother a sign (Q. 23:50) and, as already 
noted, Mary's name is always mentioned when referring to Jesus in the Qur'an. More than anyone else, she attracts sympathy and tenderness-a young woman having to go through the harrowing experience of giving birth all alone and, after that, having to face her people and their accusations. It is significant that comfort to Muhammad is given in the sura of Maryam. She, too, has to submit to God's decree, like Muhammad, who is told to be steadfast in [his] worship even if relief is not granted instantly, in the face of the accusations made against him in Part 2.

We have said earlier that the function of the sura was to respond to Muhammad's need to feel God's mercy and support. This was achieved in the following ways. First, in the first part of the sura by showing God's grace to the figures mentioned there. Secondly, in the bridging section between the two parts the Prophet is told that God is not forgetful and that he should persist in worshipping Him. Thirdly, in the final part God shows his support for Muhammad by responding to the disbelievers in a number of ways, answering logically what they say, warning them that they will face judgement in the life to come, saying that Muhammad's role is only to give good news and warning, reminding the Prophet that God has destroyed many generations of disbelievers before, and asking Can you hear any whisper from them?

We have demonstrated how Sürat Maryam was meant to bring comfort and support to the Prophet Muhammad. The sura also includes 'lessons and reminders to the believers' and beautiful descriptions of Zakariyyā's prayers to God for the blessing of a child, of John and Jesus, Ishmael and Idrīs, of the way that Abraham dealt with his father, and of how Moses was comforted, all of which give ideals of behaviour to aspire to. The repetition of the verbs habli ('grant me') and wahabnā ('we granted') must have comforted the Prophet and still, when recited by the most dramatic reciters, on radio and television, and in mosques, in the rhythmic and musical sounds of Qur'anic style, gives hope to those who listen to or read this sura that they too may have their prayers answered from the boundless grace of God.

\section{NOTES}

1 For istafāki (has chosen you, Mary) c.f. Q. 3.33 (Jesus) and Q. 38:47 (prophets); for tahharaki (has purified you, Mary) c.f. Q. 3:55 (Jesus) and Q. 33:33 (the wives of Prophet Muhammad).

2 See, for example, Alhassen, 'A Structural Analysis'; Robinson, Discovering the Qur'an; Neuwirth, Studien zur Komposition der mekkanischen Suren; and Toorawa, 'Sūrat Maryam'.

3 Toorawa, 'Sūrat Maryam', p. 33.

4 Toorawa, 'Sūrat Maryam', pp. 33-50.

5 Alhassen, 'A Structural Analysis'.

6 Alhassen, 'A Structural Analysis', p. 92. 
7 Alhassen, 'A Structural Analysis', p. 94.

8 More examples of this can be found in Suras 7, 11, 15, 21, 34, 37, 40, 41, 46, 54, and others. 9 See Abdel Haleem, chapter on Sūrat Nūḥ in Exploring the Qur'an.

10 See, for example, al-Wāhiidī, Asbāb al-nuzūl, pp. 203-205. The first verse commented on is verse 64 . The comment says that the Prophet asked Gabriel, 'Why do you not visit us more often?' giving rise to the response from the angels which comprises this verse. There is also a useful discussion on verse 77, according to which a Muslim blacksmith went to an eminent non-Muslim to ask for payment of a debt and he said, 'I will not pay you until you denounce your faith in Muhammad,' to which the blacksmith replied, 'I will not do that until you die and are resurrected again.' The non-Muslim retorted, 'Well, come to me then and I will pay you then.' This gives some further indication of the arrogance of the Meccan leaders at that time, and their oppression of the Muslims, seen in part 2 of the sura, which contributed to the psychological state of the Prophet and his community. There is no historical evidence to specify the year.

11 See George Tamer's Arabic translation of Nöldeke's Geshichte des Korans (Tamer, Tarīkh, p. xxxvi).

12 I have already collected a good amount of material and will develop this theory further.

13 al-Rāzi takes the view that the objective of this sura is to state the oneness of God, prophethood and the final gathering before God (Mafātih al-ghayb, part 21, p. 222). This could be said of Part 2 of the sura which argues with the disbelievers about these matters but surely would not apply to Zakariyyā's prayers and the crucial statement at the beginning of the sura: dhikru rahmati rabbika 'abdahu Zakariyyā.

14 Samiyy can mean 'of the same name' or 'of the same status'.

15 The phrasing used to refer to both Joseph (Q. 12:22) and Moses (Q. 28:14) reads: When he reached his full strength and manhood, We gave him sound judgement and knowledge: this is how we reward those who do good.

16 This is a better translation than 'mention', because the sura is about consoling Muhammad rather than mentioning things to other people.

17 In Sura 38, none of the many instances of $w a^{\prime}$ dhkur have fi'l-kitāb after them.

18

Q. 3:43

$19 \mathrm{God}$ is here addressed as al-rahmān, another important key name of God in this sura, combining power and mercy. See Hassan, al-Sab'al-mathānī, pp.177-174.

20 The same answer as Zakariyyā was given.

21 al-Rāzī, Mafātih al-ghayb, part 21, p. 204.

22 Alhassen, 'A Structural Analysis'.

23 Contextually this means, 'a child you are cradling in your arms'.

24 'Sister' does not necessarily mean biological sister. In Q. 17:27 spendthrifts are referred to as the brothers of Satan (ikhwān al-shayatīn). The Arabs say 'yā akh al-'Arab' ('O brother of the Arabs') meaning simply 'an Arab'. Who is Aaron then? This is not identified and could be taken as an insult or in parallel with the descriptions of her father and mother.

25 al-Rāzī reports that Abū al-Qāsim al-Balkhī said, 'Jesus said this as an adolescent who understands even though he has not yet reached the stage of takliff ('legal responsibility') (Tafsir, part 21, p. 213).

26 Alhassen, 'A Structural Analysis', p. 99.

27 Ibn 'Abbas is reported to have held this view (al-Rāzi, Mafātih al-ghayb, p. 213).

28 Alhassen, 'A Structural Analysis', p 107.

29 God also says of John in Q. 19:12, We gave him sound judgement as a boy (șabiyyan). 
30 al-Rāzī states, 'They have differed about mahd. It is said that it was her lap, based on the narration that she took him in a cloth (khirqa) and brought him to her people. When they saw her, they said what they said, and she pointed at him while he was in her lap; she did not have a home ready in which a cradle could be prepared. Otherwise, its meaning is "how can we talk to a child" whose way is to sleep in a cradle' (Tafsir, part 21, p. 208). Fascinating literature developed around this. Al-Rāzī reports (Part 21, p. 207-208), 'It has been reported from Ibn 'Abbās (may God be pleased with him) that Joseph brought Mary to a cave and took her inside for 40 days until she had been cleansed of her postpartum bleeding. She then came, carrying him, to her people, and Jesus spoke to her on the way, saying, "O my mother! Be happy, for I am the servant of God and his Messiah."'

31 Șabiyyan can mean a youth or a baby (Badawi \& Haleem, Dictionary of Qur'anic Usage). One of the meanings is 'not yet weaned', or 'younger than a ghulām' (al-Mu 'jam al-wasiț). It can cover a wide range of ages, as does 'child' in English. In such a situation the context must be the decider. It is helpful in this discussion to refer to the Gospel of Luke (Luke 2:41-52), where Jesus is left behind in Jerusalem, and when Mary and Joseph return to find him: '... after three days, they found him in the temple courts, sitting among the teachers, listening to them and asking them questions. Everyone who heard him was amazed at his understanding and his answers.' It is clear from this that he definitely was not a baby, but that he had sound judgement from a very young age.

32 al-Bukh, Saḥīh, vol. 4, bk 55, no. 645, or Wensinck Concordance, vols 5-6, p. 279: 'Bukhārī Prophets, 48, and Muslim, Birr 8'.

33 See for instance Shaltūt, al-Islām, pp. 53-65.

34 Șiddīq is an intensive form of the adjective șādiq, translated here as 'a man of truth'

35 'Peace be with you: I will beg my Lord to forgive you-He has always been gracious (hafiyy) to me-but for now I will leave you, and the idols you all pray to, and I will pray to my Lord and trust that my prayer will not be in vain.'

36 An example of this is found in Q. 37:102, where he submits to God's will to sacrifice him. He lies down obediently but is reprieved. He commands his family to pray and pay zakāt. Likewise, Muhammad is commanded in Q. 20:132, Command your family to pray and be steadfast in this.

37 Bell, The Qur'an Translated, vol. 1, p. 284.

38 This usage appears in several places in the Qur'an, including Q. 36:77, Q. 76:3, and Q. 80:17.

39 See for example: Q. 20:130, Q. 50:39, and Q. 73:10.

40 The same argument is also used in connection with Zakariyyā in Q. 19:9, when he questions how he could have a child in his old age.

41 This presumptuousness is repeated again in the Qur'an, at Q. 41:50: Whenever We let him taste some of Our mercy after he has been afflicted, he is sure to say, 'This is all my own doing: I do not think the Hour will ever come, but even if I were to be taken back to my Lord, the best reward would await me with Him.' See also Q. 18:36, which shows that this was a regular objection that vexed the Prophet.

42 For example Q. 35:4, God keeps the heavens and earth from vanishing; if they did vanish, no one else could stop them. God is most forbearing, most forgiving, and Q. 79:32.

$43 \mathrm{It}$ is clear from the immediate context that this refers to the Arabs' belief that the angels were daughters of God and should be worshipped as such, cf. Q. 43:19-20.

44 In the previous sura (Q. 18:2) the order is reversed to suit the context.

45 See also Q. 88:21-26, So [Prophet] remind them: your only task is to remind, you are not there to control them. As for those who turn away and disbelieve, God will inflict the greatest torment upon them. It is to Us they will return, and then it is for Us to call them to account. This is the third instance of radd in this sura (the others are in verses 2 and 64), the others are 
in verses 2 and 64.

\section{Bibliography}

Abdel Haleem, Muhammad, Exploring the Qur'an: Context and Impact (London: IB Tauris, 2017).

Abdel Haleem, Muhammad, and Elsaid Badawi, Arabic-English Dictionary of Qur'anic Usage (Leiden-Boston: Brill, 2010).

Alhassen, Leyla Ozgur, 'A Structural Analysis of Sūrat Maryam, Verses 1-58', Journal of Qur'anic Studies, 18:1 (2016), pp. 92-116.

Bell, Richard, The Qur'an: Translated, with a Critical Re-Arrangement of the Surahs (2 vols, Edinburgh: T. \& T. Clark January 1960).

al-Bukhārī, Saḥị̣ al-Bukhārī, tr. Mohsin Khan at www.sahihbukhari.com/Pages/Bukhari_4_55.php [accessed 25/10/2019].

Gökkir, Bilal, 'Form and Structure of Sura Maryam-A Study from Unity of Sura Perspective', Süleyman Demirel Üniversitesi Ilahiyat Fakültesi Dergisi 16:1 (2006), pp.1-16.

Ḥassan, Tammām, 'al-Sab' al-mathānī: (Q. 15:87)', Journal of Qur'anic Studies, 6:2 (2004), pp. 184-172.

Lane, E.W., Lane's Lexicon (8 vols, Beirut: Libraire du Liban, 1968).

al-Mu jam al-wasiț (Cairo: Academy of the Arabic Language, 1985).

Neuwirth, Angelika, Studien zur Komposition der mekkanischen Suren: Die literarische Form des Koran-ein Zeugnis seiner Historizität? 2., durch eine korangeschichtliche Einführung erweiterte Auflage (Berlin-New York: Walter de Gruyter, 2007).

al-Rāzī, Fakhruddin, al-Tafsīr al-kabīr, also known as Mafātiḥ al-Ghayb (Beirut, n.d.) 32 vols.

Robinson, Neal, Discovering the Qur'an: A Contemporary Approach to a Veiled Text, 2nd edn (Washington DC: Georgetown University Press, 2003).

Shaltūt, M., al-Islam 'aqīda wa-sharīa (Cairo: n.p., 1990).

Tamer, George, Tarīkh al-Qur'ān (Zurich: Konrad Adenauer Stiftung, 2000).

Toorawa, Shawkat, 'Sūrat Maryam (Q. 19): Lexicon, Lexical Echoes, English Translation', Journal of Qur'anic Studies 13:1 (2011), pp. 25-78. 
al-Wāḥidī, 'Alī b. Aḥmad, Asāb al-nuzūl (Cairo: Mu’assasat al-Ḥalabī, 1968).

Wensinck, A.J., Concordance et Indices de la Tradition Musulmane (8 vols, Leiden: Brill, 1967). 